

\section{The politics of identity}

\section{MANCHESTER 1824}

Manchester University Press 
Christine Agius and Dean Keep - 9781526110268 Downloaded from manchesterhive.com at $04 / 26 / 2023$ 12:26:48PM via free access 


\title{
The politics of identity
}

\author{
Place, space and discourse
}

\author{
Edited by \\ CHRISTINE AGIUS AND DEAN KEEP
}

Manchester University Press 


\section{Copyright @ Manchester University Press 2018}

While copyright in the volume as a whole is vested in Manchester University Press, copyright in individual chapters belongs to their respective authors, and no chapter may be reproduced wholly or in part without the express permission in writing of both author and publisher.

Published by Manchester University Press

Altrincham Street, Manchester M1 7JA

www.manchesteruniversitypress.co.uk

British Library Cataloguing-in-Publication Data

A catalogue record for this book is available from the British Library

ISBN 9781526110244 hardback

First published 2018

The publisher has no responsibility for the persistence or accuracy of URLs for any external or thirdparty internet websites referred to in this book, and does not guarantee that any content on such websites is, or will remain, accurate or appropriate.

Typeset by

Servis Filmsetting Ltd, Stockport, Cheshire 